\title{
Potential Uses of Treated Municipal Wastewater in a Semiarid Region of Mexico
}

\author{
Alfredo Valdes Ramos ${ }^{1}$, Elsa N. Aguilera Gonzalez ${ }^{1}$, Gloria Tobón Echeverri ${ }^{2}$, \\ Luis Samaniego Moreno ${ }^{3}$, Lourdes Díaz Jiménez ${ }^{4}$ and Salvador Carlos Hernández ${ }^{4, *} *$ (D) \\ 1 Comimsa, Calle Ciencia y Tecnología No. 790, Saltillo 400, 25290 Saltillo, Coahuila, Mexico; \\ alfredo.valdes@comimsa.com (A.V.R.); elsa.aguilera@comimsa.com (E.N.A.G.) \\ 2 Asociación de Usuarios del Agua de Saltillo, A.C., 25000 Saltillo, Coahuila, Mexico; gtgarza99mx@gmail.com \\ 3 Departamento de Riego y Drenaje, Universidad Autónoma Agraria Antonio Narro, Periférico Luis \\ Echeverría S/N, 25070 Saltillo, Coahuila, Mexico; lsamaniegom@yahoo.com.mx \\ 4 Cinvestav-Saltillo, SRNyE, Laboratorio de Revaloración de Residuos. Av. Industria Metalúrgica 1062, \\ Parque Industrial Saltillo-Ramos Arizpe, 25900 Ramos Arizpe, Coahuila, Mexico; lourdes.diaz@cinvestav.mx \\ * Correspondence: salvador.carlos@cinvestav.mx; Tel.: +52-844-4389600 (ext. 8524)
}

Received: 31 January 2019; Accepted: 9 April 2019; Published: 12 April 2019

check for updates

\begin{abstract}
This paper presents an assessment of three potential applications of municipal treated wastewater in a semiarid region of northern Mexico. The potential applications considered are agriculture, industry, and watering urban green areas. The results indicate that in the best scenario, the maximal application of treated wastewater is $150 \mathrm{~L} / \mathrm{s}$ for industrial activities. Besides industrial applications, this scenario would allow farmers and urban green areas to receive $980 \mathrm{~L} / \mathrm{s}$ and $70 \mathrm{~L} / \mathrm{s}$ of treated wastewater respectively. Other issues and alternatives are also identified. With the implementation of this scenario, it is possible to improve the environmental, and even the socioeconomic conditions, of the study region.
\end{abstract}

Keywords: wastewater reuse; groundwater depletion; irrigation of green areas; wastewater in agriculture

\section{Introduction}

Water is one of the most important resources for promoting socioeconomic and industrial development of any society. In arid and semiarid regions, water relevance is even more remarkable since economic activities can be limited by this resource. For example, the kind of agriculture, animal husbandry, and industry depends directly on the availability of water. Furthermore, the management of water is essential at all stages: extraction, distribution, wastewater gathering, treatment and use of treated wastewater.

The utilization of treated wastewater implies benefits and risks as has been shown in many studies. These benefits include: reducing both stress on water bodies and pollution of freshwater [1]; decreasing fertilizer need since treated wastewater contains nutrients available for plants [2]; facilitating conservation and management of freshwater resources, thus increasing the availability of water for urban use [3] and improving economics since the price of treated water is generally lower than that of fresh water [4]. On the other hand, different risks have also been identified. In irrigation applications, it causes accumulation of chemical and biological contaminants in soil, which affects both physicochemical and microbiological properties of the soil, and subsequently its productivity and fertility [5,6]; certain persistent pollutants could also enter the food chain through crops irrigated with treated water [5]. For some industrial applications, tertiary, and even quaternary, treatment processes should be included, thus increasing the complexity of the treatment systems and their operation $[3,7,8]$. 
For these reasons, it is important to evaluate the water quality and the potential applications to include treated wastewater in integral water management strategies.

Nowadays, the use of treated wastewater is an extended practice worldwide, especially in arid and semiarid countries. Different studies describe experiences, plans, and recommendations for applications of treated water, considering social, economic, environmental and other factors [8-15]. A study in South Africa concludes that the factors considered for implementing wastewater reuse are the distance to transport the water, retrofitted versus new installations, quantity of reuse, pricing, source quality, public health, willingness, public trust and knowledge, and regulations and guidelines for reuse [9]. An assessment in the West Bank of the Palestinian territory found that the participation of farmers in developing guidelines, standards, policies, and plans for agricultural reuse is very important for the sustainability of treated wastewater reuse [10]. From numerical simulations, based on the Israel experience of agricultural reuse of treated wastewater, it was determined that the reuse of treated wastewater has increased the country welfare by 3.3 billion USD; elsewhere, desalination of treated wastewater is expensive and not optimal since the agricultural benefits do not compensate the costs [4]. A life cycle assessment was performed by Moretti et al. [16] to study the environmental impact of reusing treated water in agriculture; the authors found that the treatment process affects the impact of treated water applications. Then, they propose to include the technology, the replacement of fertilizers, the effects on water availability and ecosystem quality as factors to redefine regulations related to reuse of treated wastewater in agriculture. On the other hand, people from Qatar are working on the implementation of processes to improve treated wastewater quality for applications such as irrigation, district cooling and domestic purposes [17]. An analysis of the challenges and opportunities for reusing treated wastewater in Turkey was reported [18]; the authors found that agriculture and urbanization (including watering of green areas) are some of the main applications in that country, and that the challenges to overcome are related to social acceptance, lack of framework of guidelines for safe treated wastewater reuse and human health risks. Besides, China is encouraging wastewater reuse in its water management strategies [7]; the main identified challenges are focused on increasing the pace in adopting urban wastewater reuse programs, the establishment of integrated water resources management framework and guidelines for wastewater reuse programs, redefining water quality requirements, increasing the market of reclaimed water and the strengthening of public awareness and cooperation among stakeholders. Also, Garcia and Pargament [19] proposed a methodology to evaluate the feasibility of reusing treated water in parks irrigation in Yarqon, Israel; they found that the factors influencing the feasibility are the recreational value of the parks watered by reclaimed water, the price of treated water, the investment and maintenance cost of the infrastructure, and the environmental effects of reusing treated wastewater. Finally, the integration of advanced treatment units such as sand filtration, coagulation and filtration, dissolved air flotation, membrane bio reactor, micro-filter, reverse osmosis, activated carbon, and ozonation are considered to be essential to reach industrial requirements for treated wastewater [13,20].

In the case of Mexico, the requirements for treated wastewater and its reuse are regulated by the national standards NOM-001-ECOL-1996 [21] and NOM-003-ECOL-1997 [22]. The former defines permissible limits for pollutants for water reuse activities, as well as the characteristics of effluent discharge into federal water bodies. The latter is dedicated to determining the conditions for wastewater reuse: criteria for sampling, testing and disposal, parameters for fecal coliform and helminth eggs, and the maximum permissible limits of chemical and biological pollutants in surface water bodies for reuse activities. On the other hand, according to the National Water Board (CONAGUA) [23], in 2017 there were 2526 municipal wastewater treatment plants in the country. They treated 135,600 L/s of wastewater, which corresponds to $63 \%$ of the country's total water recovered from sewage systems. That year also recorded an estimated reuse rate of $39,800 \mathrm{~L} / \mathrm{s}$ directly from treatment plants and $78,800 \mathrm{~L} / \mathrm{s}$ after disposal to a water body [23]. Nevertheless, wastewater is often reused without treatment in irrigation of crops and some industrial applications and services [24,25]. In recent years, the reuse of treated wastewater is gaining interest in different regions of the country, especially in 
the northern and mainly for agricultural activities [26-29]. But in general, the water infrastructure does not include reusing systems; in addition, the initiatives to expand the applications of treated water are still few. These situations imply important challenges which should be addressed in strength collaboration among government, industrialists, academic and social sectors.

The literature review points out the importance of treated wastewater as a new water source. Among the challenges and opportunities in the implementation of strategies for reusing treated wastewater are the selection of applications, the technical and economic feasibility, the social acceptance, the local regulations and the environmental effects. The contribution of the paper presented here is related to the application of the methodology since most of the reviewed papers identify the possible applications of treated wastewater and focuses on one of them, e.g., agriculture, industry, urbanization, etc. Few studies have addressed the reuse of reclaimed water on simultaneous applications with a systematic perspective. Thus, the objective of this study is to assess three potential applications of treated wastewater in a semiarid region (Saltillo-Ramos Arizpe, Coahuila, Mexico): agricultural activities, industrial activities, and irrigation of urban green areas. These applications were selected based on their environmental, social, and economic relevance for the region. Agriculture has been a historically important activity, but for some years now, conditions for farmers have become worsened (e.g., the weather and reduced availability of water); the re-activation of this activity is important from social and economic viewpoint for the region. Industrial development and promotion require copious amounts of water. Lastly, urban green areas are an important element for quality of life according to the World Health Organization (WHO) [30]. Some other non-drinking uses (laundry, cleaning, bathing, flushing toilets, etc.) are excluded since there is not infrastructure to distribute and reuse treated water at homes and specific buildings, and implementing it becomes too expensive. An additional aim of the paper is related to the integration and analysis of information and the assessment of potential scenarios for wastewater treatment. Since this is the first study related to the potential of wastewater in the region, it could be used as a guide to take decisions concerning the applications of treated wastewater, the kind of enterprises to be installed and even the location of new residential developments. In this context, the analysis presented in the paper is directly related to the compromises of Mexico in the frame of the 2030 Agenda for Sustainable Development [31]. The Goal 6 (ensure availability and sustainable management of water and sanitation for all) includes as third target "to improve water quality by reducing pollution eliminating, dumping and minimizing release of hazardous chemicals and materials, halving the proportion of untreated wastewater and substantially increasing recycling and safe reuse globally". Then, this work proposes alternatives to contribute to fulfill this target, specifically in relation to the reuse of treated wastewater. Finally, this study allows the local researches to select the more relevant topics since the main issues of treated wastewater have been identified.

\section{Context of the Studied Region}

The studied region is located at the southeast of Coahuila, Mexico, and comprises two municipalities: Saltillo and Ramos Arizpe (Figure 1). The total landmass is 557,860 ha and includes about 780,000 inhabitants, most of whom live in urban areas. It is classified as a semiarid region since the annual precipitation is $370 \mathrm{~mm}$, the annual average maximal temperature is around $38^{\circ} \mathrm{C}$ and some years more than $40^{\circ} \mathrm{C}$ have been registered (according to data from the National Meteorological Service). This is one of the most important industrial regions of the country and it is situated at $60 \mathrm{~km}$ of Monterrey, the third-largest metropolis in Mexico.

In past decades, agriculture was one of the main economic activities on the Saltillo-Ramos Arizpe region. More than 4000 ha were designated to this activity being vegetables and fodder the main products. This surface represents $0.72 \%$ of the landmass of the study region (557,860 ha) and is equivalent to $\sim 15 \%$ of the urbanized area in accordance with the development program for this metropolitan area [32]. The water required was provided from a natural stream called Arroyo La Encantada, which was essential to the social development of the region. Around 1970, urban wastewater was disposed of in that natural stream without any treatment. Water pollution caused 
three main consequences: (i) natural recreational areas were lost, (ii) some species of fish disappeared, and (iii) CONAGUA forbade the irrigation of vegetables, and agriculture was reduced to growing only fodder crops (fodder oats, fodder barley, grass, sorghum, alfalfa, forage corn) and beans; currently, only around 2500 ha are dedicated to agricultural activities. The total surface water exploitation for agriculture is around $360 \mathrm{~L} / \mathrm{s}$ [33]. A consequence of the decrease in vegetables production marked the beginning of a shift in economic activities. Manufacturing of clay-based bricks, and tiles was a relevant source of employment for people. Presently, this region is the site of the most important industrial park in Coahuila State and is one of the most economically proficient areas in the country. In agreement with the records of the National Institute of Statistics, Geography and Informatics (INEGI), more than 170 industries are in the study region, consuming around $330 \mathrm{~L} / \mathrm{s}$ of water $[23,34]$. New enterprises are established each year since the local government promotes industrial development. This implies the creation of new employment opportunities and a dynamic economy, but it is also associated with an increasing population and the subsequent need for more services such as energy, water, shopping, and communication. On the other side, according to the municipalities, an estimated of $6.6 \mathrm{~m}^{2}$ and $5 \mathrm{~m}^{2}$ of urban green areas exist per inhabitant in Saltillo and Ramos Arizpe, respectively; however, there is little information available concerning the amount of water used for irrigation.

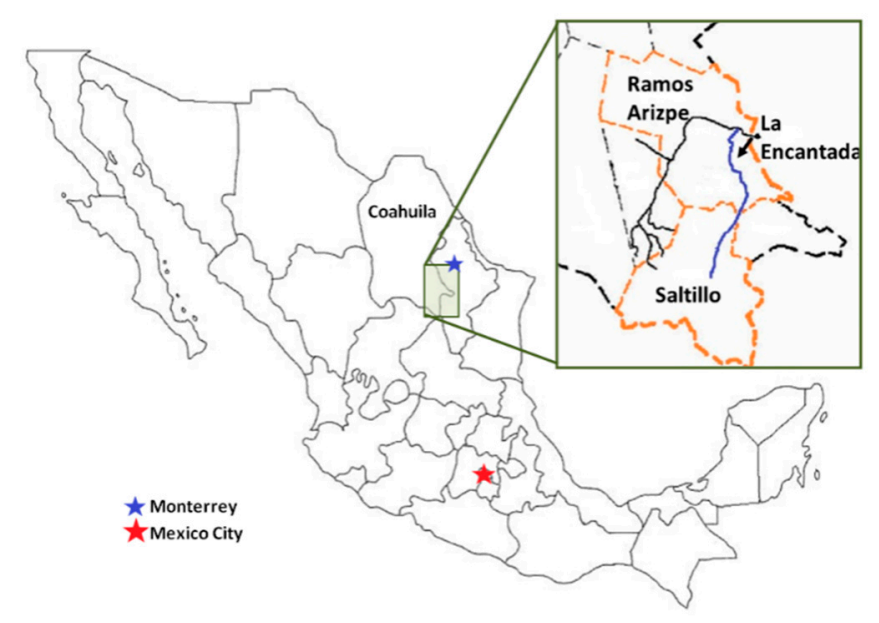

Figure 1. Geographic location of the study region.

According to official data, the renewable water resources (RWR) per capita is $0.032 \mathrm{~L} / \mathrm{s}$ [26]; even if this value could fluctuate over the years, it is representative of the region. Water is extracted from four aquifers. In agreement with the data provided by the Secretariat of Environment and Natural Resources (SEMARNAT), three of these aquifers present deficit, as shown in Table 1 [35]. As for RWR, this situation characterizes well the condition of the region in this decade.

Table 1. Water balance of aquifers in the study region.

\begin{tabular}{ccccc}
\hline Aquifer & Total Recharge (L/s) & Total Discharge (L/s) & Balance (L/s) & Status \\
\hline Saltillo-Ramos Arizpe & 2749.24 & 2948.69 & -199.45 & Deficit \\
Saltillo Sur & 415.40 & 415.40 & 0.00 & - \\
Derramadero Canyon & 570.78 & 904.68 & -333.90 & Deficit \\
Zapalinamé & 1759.89 & 2024.99 & -265.09 & Deficit \\
\hline
\end{tabular}

On the other hand, the region is home to three municipal wastewater treatment plants (WWTPs), the locations of which are illustrated in Figure 2 . The total installed capacity $(1430 \mathrm{~L} / \mathrm{s})$ of these WWTPs is $1200 \mathrm{~L} / \mathrm{s}, 70 \mathrm{~L} / \mathrm{s}$, and $160 \mathrm{~L} / \mathrm{s}$, respectively. The Saltillo principal plant (SPP) includes a tertiary system based on reverse osmosis, but it treats only $20 \mathrm{~L} / \mathrm{s}$ of wastewater. 


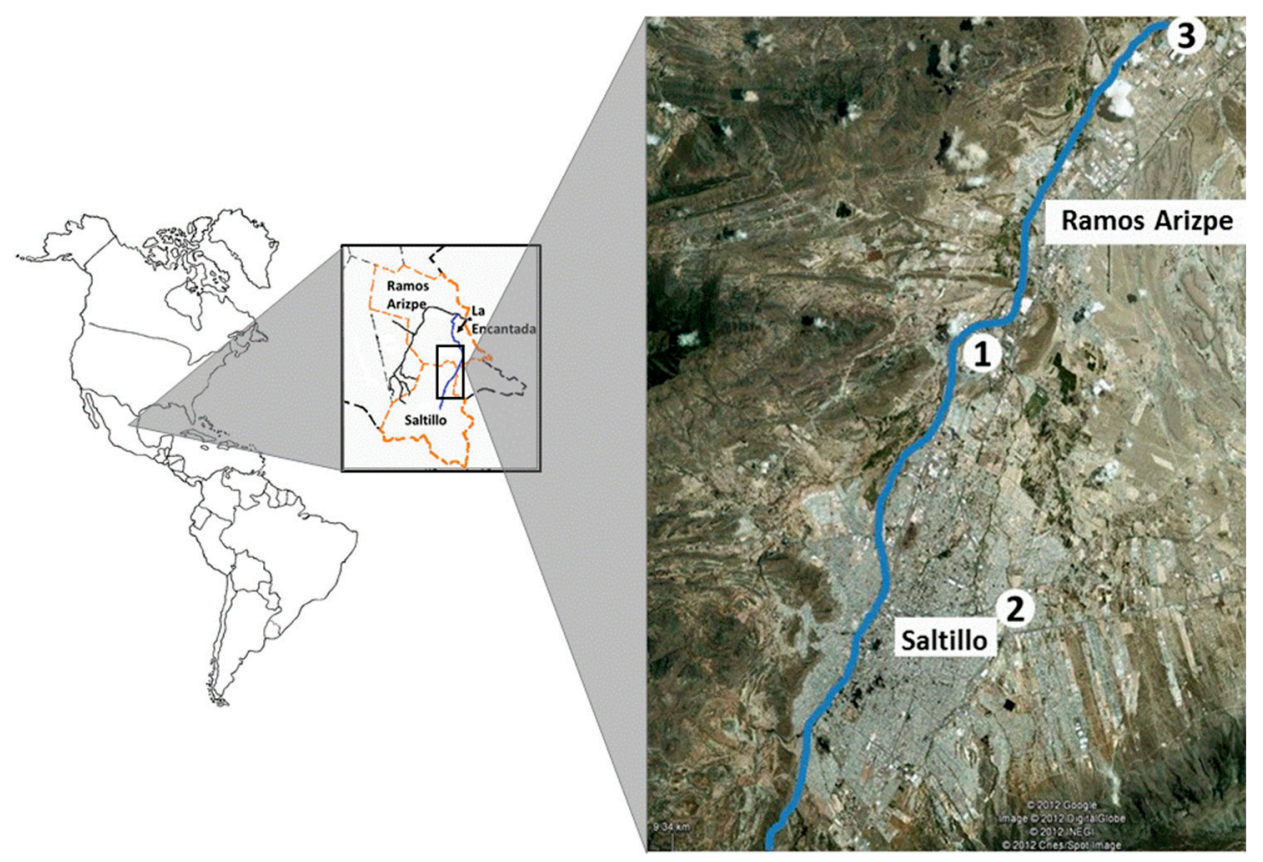

Figure 2. Location of the wastewater treatment plants: 1 Planta Principal de Saltillo (Saltillo principal plant-SPP), 2 Planta del Gran Bosque Urbano (big urban forest plant -BUFP), and 3 Planta Municipal de Ramos Arizpe (Ramos Arizpe municipal plant-RAMP).

\section{Methods}

The methodology used to perform this study was developed based on reported works. The determination of wastewater quality, the reuse alternatives selection, the social acceptance, the techno-economic feasibility, health and environmental effects, local regulation among other factors are usually considered in the strategies for treated wastewater management $[4,7,9,10,36]$. Most of these factors were taken into account to adapt reported frameworks to the case of study. A graphical representation of the resulting proposed methodology is divided in five steps; it is introduced in Figure 3 and explained below.

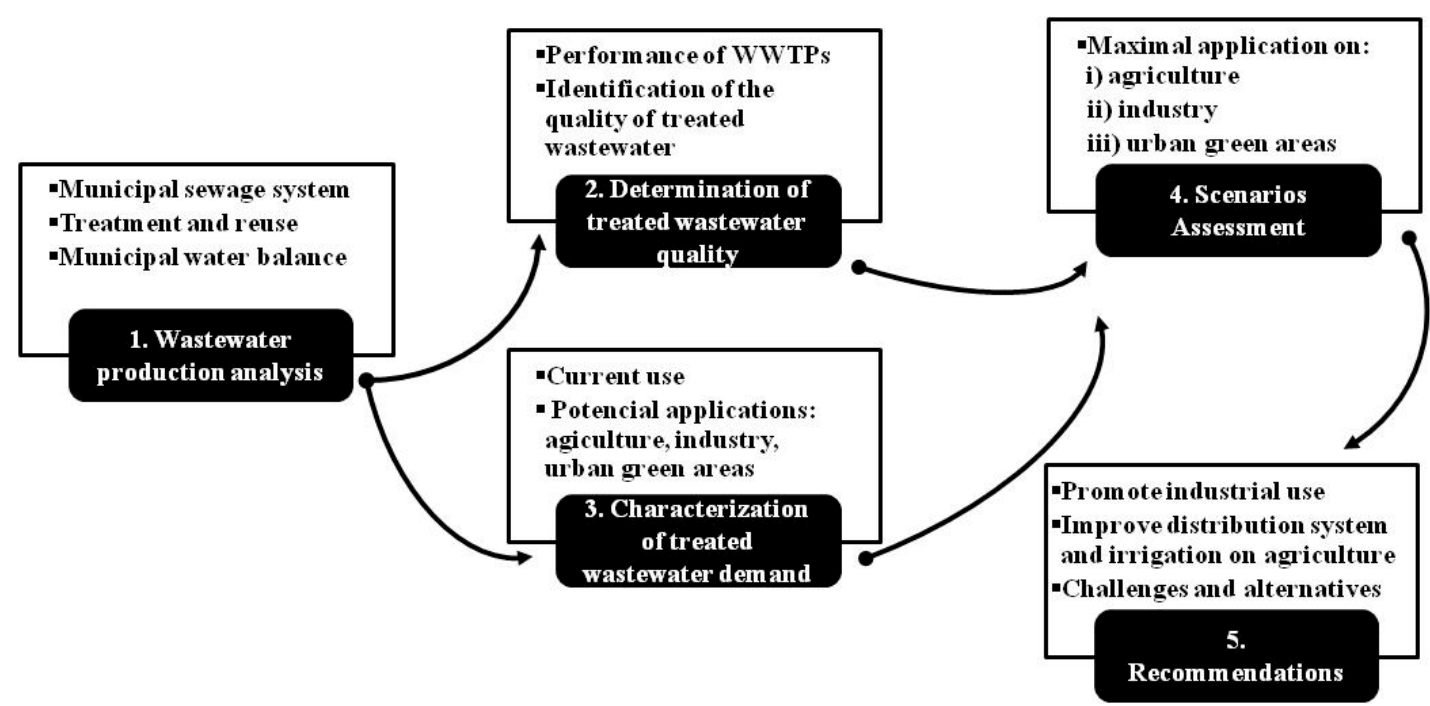

Figure 3. Flow diagram of methodology used in this study. 


\section{Step 1. Wastewater Production Analysis}

A wastewater balance on the municipal sewage system was performed to determine the production and gathering of wastewater. It was assumed that each inhabitant uses $0.0021 \mathrm{~L} / \mathrm{s}$ of water and produces $0.0018 \mathrm{~L} / \mathrm{s}$ of wastewater. These values were estimated based on information from the companies managing water resources in the study region as well as from an empirical analysis of the social habits regarding water consumption in the region. Besides, in situ inspections of the municipal sewage systems were performed in order to determine the water flow in the region.

\section{Step 2. Characterization of Treated Wastewater}

The quality of the treated wastewater was determined by physicochemical and microbiological analyses. The Mexican standards were considered as reference to determine the water quality: NOM-001-ECOL-1996 [21] and NOM-003-ECOL-1997 [22]. Both standards are based on the guidelines for using treated wastewater in agriculture developed by the WHO [30]. The methodology and data obtained were reported previously [37], and the main results are included in Section 4.2 of this paper.

\section{Step 3. Determination of Treated Wastewater Demand}

The main applications for treated wastewater, namely agriculture, industrial applications, and urban green areas, were selected based on the environmental, social, and economic relevance for the region. Agriculture has been a historically important activity, but for some years now, conditions for farmers have become worsened. Industrial development and promotion require copious amounts of water. Lastly, urban green areas are an important element for quality of life according to the WHO [30]. The data used to determine treated wastewater volume required for the three applications were obtained directly from the potential users. With this objective, six ad-hoc workshops were organized considering the next general schedule:

- Opening remarks: workshop introduction, description of the motivation, objectives and day work dynamics.

- Specific lectures: presentation related to the relevance of treated wastewater reuse in the region by the team leader. Presentation of experiences in the industry, agriculture or urban greening by invited people.

- Discussion: discussions related to the water requirement status and expressions of interest for treated wastewater.

- Survey. The assistants completed a survey to identify the current consumption of fresh water and treated wastewater as well as to know the perspectives for using treated wastewater. The questionnaire is available as Additional Material.

- Closing remarks.

The workshops were organized as follows:

- One industry workshop. An open invitation for industrialists was issued, and personalized invitations were sent to the largest industries in the region. This workshop was attended by 17 representatives from industries (responsible of operations and people from the administrative department) located at Ramos Arizpe, two from municipal authorities and two from the municipal water managers. The assistance from industries was lower than expected; however, the largest enterprises in the region were represented. To complement the information, appointments were arranged by phone and the surveys were sent at that moment by email; this allowed the responsible to collect the required information. The day of the appointment the survey was completed by a member of the authors together with the responsible of the industry. The industries for the survey application were selected based on their size and their main activity.

- Four agriculture workshops. The first workshop was developed by the authors of this paper and municipal authorities to design the survey and to organize the other events. The second workshop 
was a work meeting with commissaries of ejidos (communal lands). The third and four workshops were mainly destined to the survey application, which has been performed as an interview. The questionnaire (available as additional material) was answered by $70 \%$ of the farmers.

- One urban workshop. Municipal authorities and people from the water management enterprises were invited. This workshop was attended by two municipal government representative and four from the management enterprises. All the invited persons were represented in the work journey.

Concerning the application of treated water for urban greening, a virtual analysis using Google Earth $^{\mathrm{TM}}$ software was performed to identify the number and distribution of green areas in Saltillo and Ramos Arizpe. Also, in situ inspections were conducted to verify the virtual information and identify the type of vegetation and the status of the green areas. From the obtained information, it was determined that each hectare of the green areas require $0.9 \mathrm{~L} / \mathrm{s}$ of water to support vegetation and maintain adequate living conditions.

\section{Step 4. Scenarios Assessment}

Three distribution scenarios were proposed based on the treated wastewater demand. Each scenario supposes one application as the priority and the other two as secondary necessities. After that, the idea is to supply first the demand on the priority application. The scenarios are called as follows. Scenario 1: maximal application on agriculture, Scenario 2: maximal application on industry, and Scenario 3: maximal application on urban greening. They were assessed by considering economic, social and environmental factors. Next were the specific criteria to identify the best scenario:

- Coverage of the demand. The larger coverage, the better the scenario. This criterion is selected since it is supposed that a larger coverage of the demand implies more benefits related to water availability for the proposed applications.

- Cost of implementation. The lower cost and larger revenues, the better the scenario. The criterion is associated to the implementation complexity in terms of investment and money recovering from the sale of treated wastewater. A lower cost was selected since, usually, this increases the possibility to convince local authorities and stockholders to promote reuse of treated wastewater.

- Environmental protection. The more benefits, the better the scenario. The criterion corresponds to environmental benefits such as the protection to ecosystems, effect on water bodies, etc.; this is selected since water has a direct influence on the ecosystems environmental quality.

- Social benefits. The more benefits, the better the scenario. This criterion is selected due to its effect on life quality for farmers and urban inhabitants.

\section{Step 5. Recommendations}

Based on the findings on the previous steps, some key aspects for future works are identified and some recommendations are presented to motivate wastewater reutilization in the region. An important remark is that the study presented in this paper was limited to the actions described in the next lines:

- The estimation of the investment for infrastructure. Details about characteristics of the technology, costs for equipment and operation were not presented in order to ease the analysis and interpretation of the included information. At the same time, an estimation of the economic and environmental benefits from the sale of wastewater was performed.

- Some other potential applications of treated wastewater such as purification for drinking, fire control, car washing, soil compression and non-drinking uses in household activities were not considered in this study due to the low volume required on the region for these applications and the missing of infrastructure. However, it was possible to take them into account for future works.

- A specific assessment of the social acceptability was not performed but it was estimated from surveys applied to farmers and industrialists and from the experience of the water management enterprises. 


\section{Results and Discussion}

\subsection{Wastewater Production Analysis}

From the water balance whereby $1322 \mathrm{~L} / \mathrm{s}$ of wastewater was identified, which corresponds to $82 \%$ of the produced amount (Figure 4). The other $18 \%$ is lost through pipe leakages, evaporation, non-return water and irregular practices. An important remark is that non-treated wastewater represents $30 \%$ $(400 \mathrm{~L} / \mathrm{s})$ of the returned water; this is due mainly to the incompleteness of the sewage systems and then it is directly discharged on natural streams. This situation induces environmental and human health impacts. Due to the temperature of the region, polluted water could cause insect proliferation inducing human health risks. Besides, untreated wastewater on natural streams promotes eutrophication affecting aquatic biodiversity, even at the microorganism level [38]. Also, wastewater contains potentially harmful pathogens, antibiotic resistant bacteria and even toxic or biologically disruptive chemicals, which could affect human health for exposed population, as reported in Contreras et al. [39]. Besides, emerging pollutants, such as pharmaceuticals, personal care products, hormones and others are being detected in urban wastewater; these pollutants increase the risk of diseases [40].

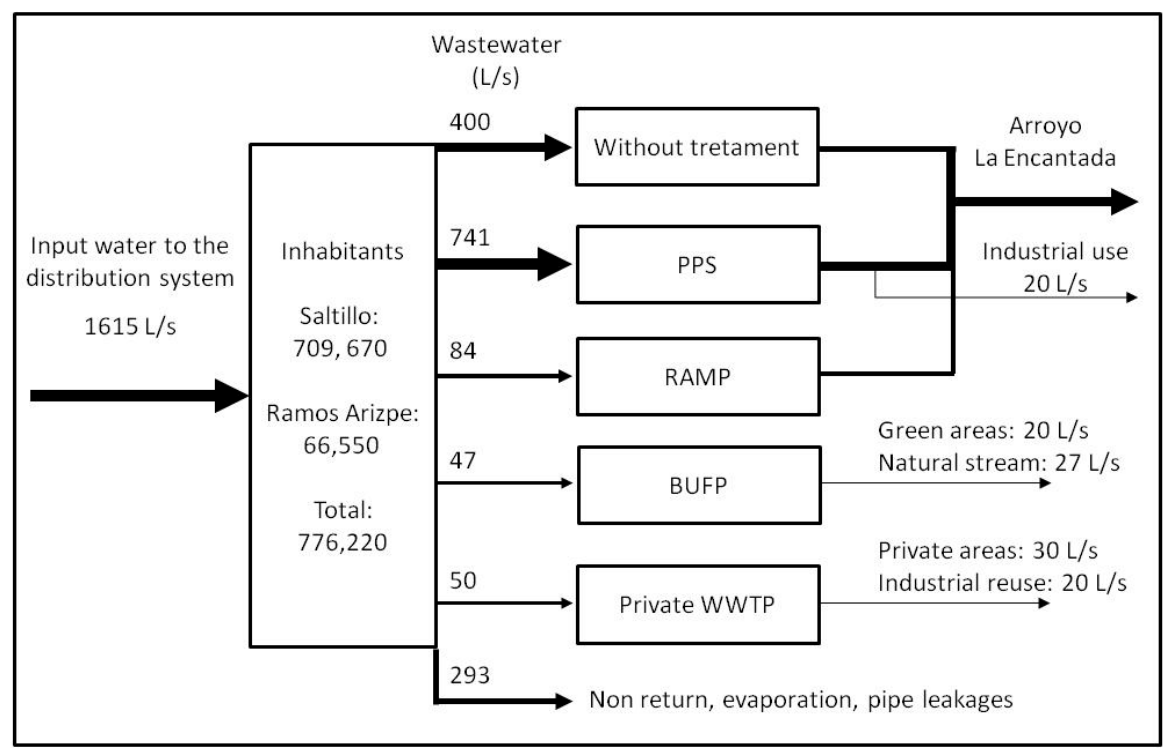

Figure 4. Water balance in the study region.

On the other hand, municipal plants treat $66 \%(872 \mathrm{~L} / \mathrm{s})$ and private plants treat $4 \%(50 \mathrm{~L} / \mathrm{s})$ of the returned wastewater. The reuse of treated water represents $4.5 \%$ of the effluent from the municipal WWTP. This amount is like the corresponding in Monterrey (4\%) and not too far from the one of Mexico City (10\%). However, in Saltillo and Ramos Arizpe, this volume of reuse is low since the region is semi-arid and presents water scarcity. This situation represents important opportunities. In fact, due to the total installed capacity, it is possible to treat all the produced wastewater and then to increase the available volume to supply treated water to different applications as done in Mexico City.

\subsection{Wastewater Characteristics}

The parameters considered in determining the quality of treated wastewater from the three WWTPs are presented in Table 2. The guidelines proposed by the Food and Agriculture Organization (FAO) and by the United States Environmental Protection Agency (USEPA) are included for comparison purposes. 
Table 2. Characterization of treated wastewater.

\begin{tabular}{|c|c|c|c|c|c|c|}
\hline Parameter & SPP & BUFP & RAMP & NOM & $\begin{array}{l}\text { WHO }^{3} \\
\text { (FAO) }{ }^{4}\end{array}$ & USEPA $^{5}$ \\
\hline $\mathrm{BOD}_{5}(\mathrm{mg} / \mathrm{L})$ & 30 & 6 & 30 & $150^{1}(20,30)^{2}$ & - & 30 \\
\hline TSS $(\mathrm{mg} / \mathrm{L})$ & 19 & 4 & 8 & $150^{1}(20,30)^{2}$ & - & 30 \\
\hline $\mathrm{pH}$ & $7.4-8.0$ & $7.1-8.0$ & $6.3-7.5$ & & $(6.5-8)$ & $6.5-8.5$ \\
\hline Conductivity (dS/m) & 1.724 & 1.336 & 2.250 & - & $(0.7-3)$ & $0.7-3$ \\
\hline Fecal coliforms (MPN/100 mL) & 500 & 240 & 200 & $(240,1000)^{2}$ & 1000 & 200 \\
\hline Helminth eggs $(\mathrm{HH} / \mathrm{L})$ & 0 & 0 & 0 & $1^{1}(1,5)^{2}$ & 1 & 1 \\
\hline Fat and grease & $<15$ & $<15$ & 10 & $(15,15)^{2}$ & - & - \\
\hline Nitrogen $(\mathrm{mg} / \mathrm{L})$ & $<40$ & $<40$ & 26.7 & $40^{1}$ & $(5-30)$ & $5-30$ \\
\hline Phosphorous (mg/L) & $<20$ & $<20$ & 6.89 & $20^{1}$ & - & - \\
\hline Heavy metals & & & & & & \\
\hline Arsenic (mg/L) & $<0.2$ & $<0.2$ & $<0.2$ & $0.2^{1}$ & $(0.1)$ & 0.1 \\
\hline Cadmium (mg/L) & $<0.5$ & $<0.5$ & $<0.5$ & $0.2^{1}$ & $(0.01)$ & 0.01 \\
\hline Cyanide (mg/L) & $<2.0$ & $<2.0$ & $<2.0$ & $1^{1}$ & - & - \\
\hline Copper (mg/L) & $<4$ & $<4$ & $<4$ & $4^{1}$ & $(0.2)$ & 0.2 \\
\hline Chromium (mg/L) & $<0.5$ & $<0.5$ & $<0.5$ & $1^{1}$ & $(0.1)$ & 0.1 \\
\hline Mercury (mg/L) & $<0.005$ & $<0.005$ & $<0.005$ & $0.01^{1}$ & - & - \\
\hline Nickel (mg/L) & $<2$ & $<2$ & $<2$ & $2^{1}$ & $(0.2)$ & 0.2 \\
\hline Lead (mg/L) & $<0.5$ & $<0.5$ & $<0.5$ & $0.5^{1}$ & $5^{6}$ & $5^{6}$ \\
\hline Zinc $(\mathrm{mg} / \mathrm{L})$ & $<10$ & $<10$ & $<10$ & $10^{1}$ & (2) & 2 \\
\hline
\end{tabular}

SPP: Saltillo Principal Plant, BUFP: Big Urban Forest Plant, RAMP: Ramos Arizpe Municipal Plant, NOM: Mexican Standard, WHO: World Health Organization, FAO: Food and Agriculture Organzation, USEPA: United States Environmental Protection Agency. ${ }^{1}$ NOM-001-ECOL-1996. ${ }^{2}$ NOM-003-ECOL-1997 (human direct contact, human indirect contact). ${ }^{3}$ Health guidelines for the use of wastewater in agriculture and aquaculture of the WHO. ${ }^{4}$ Wastewater treatment and use in agriculture-FAO. ${ }^{5} 2012$ Guidelines for Water Reuse of the USEPA. ${ }^{6}$ For irrigation.

Elevated conductivity is mainly due to salts and can cause corrosion or encrustation on metallic surfaces. This affects the operation of industrial and domestic equipment such as boilers, pipelines, flushing mechanisms, washing machines, and others. In addition, water with high conductivity could negatively affect vegetal species and even cause the elimination of desirable plants. The SPP and big urban forest plant (BUFP) produce better treated water than the Ramos Arizpe municipal plant (RAMP) with respect to conductivity. The value obtained from the RAMP could limit the use of that treated water for industrial applications [13]. Nevertheless, it is possible to use tertiary treatment processes, such as reverse osmosis, stabilization ponds, and membrane bioreactors, among others [41,42]. Furthermore, it has been reported that for specific industrial processes, some pollutants could produce positive impacts [43]; freshwater replaced by wastewater (from a process producing methanol) employing a mass flow exchange technique. This improves the absorption capacity of the studied system; even if it is a very particular application, the methodology could be adapted to local conditions in semiarid regions.

Fecal coliform content is one of the main parameters that determines the viability of applying treated water to water food crops [44-47]. The presence of fecal coliform content does not restrict industrial applications; however, treated water should have a minimal content. The SPP effluent does not fulfill the standard for urban greening in applications of direct human contact. But, the three WWTPs fulfill the official standard of this parameter, which is $1000 \mathrm{MPN} / 100 \mathrm{~mL}$. Biological oxygen demand (BOD) is an index of the presence of organic material in the treated water. The official regulations state that the maximal permissible levels of organic pollutants in treated wastewater used for public services with indirect human contact must be less than $30 \mathrm{mg} B O D / L$ and $20 \mathrm{mg} \mathrm{BOD} / \mathrm{L}$ for direct human contact. As such, for direct contact applications, only the BUFP fulfills the respective standard. However, the three effluent streams are suitable for agricultural activities and green areas with indirect contact. Finally, the three WWTPs fulfill the permissible limits for total suspended solids (TSS). The SPP effluent has $19 \mathrm{mg} / \mathrm{L}$, which could be restrictive for some applications. At present, a 
tertiary treatment based on reverse osmosis decreases this parameter to $10 \mathrm{mg} / \mathrm{L}$ in the SPP; $20 \mathrm{~L} / \mathrm{s}$ is treated in this way, and this volume is sold to an industry located about the SPP.

The treated wastewater fulfills the Mexican standards and most of the WHO, FAO and USEPA guidelines. Then, it can be deduced that the produced wastewater in the region is feasible to be reused in several applications such as crops irrigation, green urban watering, laundry, cleaning, water bodies recharge, household applications and even some industrial processes.

\subsection{Identification of Treated Wastewater Demand}

\subsubsection{Agriculture Sector}

From the agriculture workshops, the current situation of agriculture sector was identified directly from farmers. The main data of agriculture in the region are presented in Table 3.

Table 3. Highlights of the agriculture activities in the study region.

\begin{tabular}{ccl}
\hline Description & Amount & \multicolumn{1}{c}{ Observations } \\
\hline Water flow in La Encantada & $\sim 1100 \mathrm{~L} / \mathrm{s}$ & $\begin{array}{l}\text { Discharged from SPP and RAMP, untreated } \\
\text { household wastewater, and industries }\end{array}$ \\
\hline Concessions & $\sim 360 \mathrm{~L} / \mathrm{s}$ & Surface water exploitation \\
\hline Land surface & $>4000 \mathrm{ha}$ & Available for agriculture \\
\hline Active surface & $\sim 2500$ ha & $\begin{array}{l}\text { Used to raise fodder crops (fodder oats, fodder } \\
\text { barley, grass, sorghum, alfalfa, and forage) }\end{array}$ \\
\hline Production & 5000 ton & Crop yield: $\sim 3.6$ ton/ha \\
\hline Production/water yield & $0.13 \mathrm{~kg} / \mathrm{m}^{3}$ & Low production yield \\
\hline Revenues & $660,000 \mathrm{USD}$ & Economic yield: 133 USD/ton \\
\hline Acceptance of treated wastewater & $\sim 70 \%$ & $\begin{array}{l}\text { Farmers expressed the willingness to integrate } \\
\text { an irrigation unit around La Encantada }\end{array}$ \\
\hline
\end{tabular}

The water flow in the Arroyo La Encantada was estimated based on measurements at different points of width and depth of the water source, as well as the superficial speed of water, and roughness [48]. It is worthwhile to remark that ninety percent of the flow rate is used for agriculture and farming without any control, leading to low efficiency and productivity. Another important remark concerns the concessions for surface water exploitation which reach only 11,400,000 $\mathrm{m}^{3} /$ year $(\sim 360 \mathrm{~L} / \mathrm{s})$; this volume is less than $20 \%$ of the water required for fodder crops in a similar area. Assuming all the available area was used to grow fodder plants, a water deficit of $\sim 57 \mathrm{Mm}^{3} /$ year $(\sim 1800 \mathrm{~L} / \mathrm{s})$ is estimated. This value exceeds $100 \%$ of the wastewater volume generated in Saltillo and Ramos Arizpe. That means agricultural activities could easily utilize the entire effluent volume released by the three municipal WWTPs.

On the other hand, the low production yield could be due to the low efficiency of watering techniques and large leakages in the water conduction system owing to unlined canals. Besides, the economic yield is directly associated to the kind of crops. The farmers expressed their willingness to raise crops with higher value which could increase revenues. It is worth mentioning that in other regions of Mexico and other areas around the world that experience similar weather, the production yields of fodder crops such as alfalfa, fodder oats, and fodder flower exceed 12 ton/ha [49-55]. As such, the results of the current study shed light on the need to improve the treated wastewater distribution system that supplies water to agricultural areas and to use better irrigation techniques. Implementing these actions would help increase the production yield. If the product/surface relationship reaches 10 ton/ha, the fodder production of the Ramos Arizpe region could rise to 13,730 ton, with a global value of almost thrice the current production. 


\subsubsection{Industrial Sector}

The main industrial parks (marked with letters symbols in Figure 5) are located north of the Ramos Arizpe urban area as well as south of Saltillo in the Derramadero Industrial Park (A in Figure 5). The main industries are related to metals and mechanized activities (car assembly, automotive parts manufacturing, and steel mills), refractory and cement production, fertilizer production, pharmaceutical production, and paper recycling to produce diapers and sanitary towels. From the discussion developed in the industry workshop, the following information was generated.

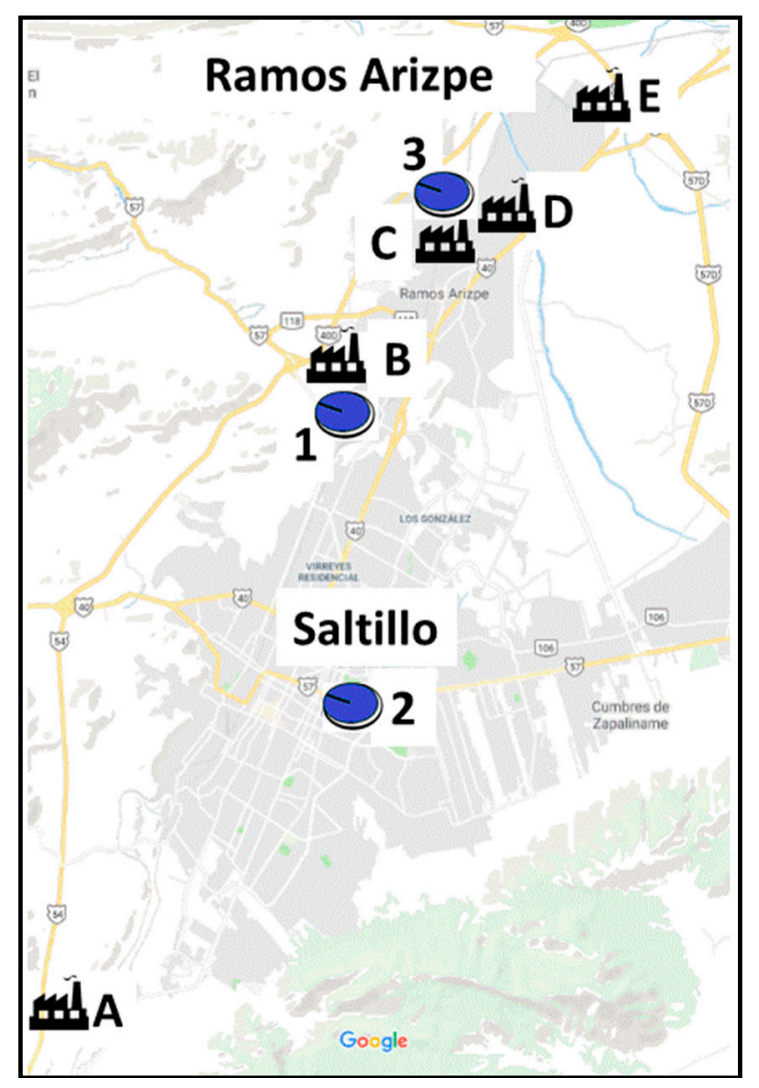

Figure 5. Location of main industrial parks.

Transporting the treated water to Derramadero requires a large investment as the water needs to be pumped for around $35 \mathrm{~km}$ and the land is placed at a slope of $500 \mathrm{~m}$. On the other hand, the geographic position of the SPP allows the treated water to be conveyed by gravity to the industrial parks situated in Ramos Arizpe. Therefore, at present time, the reuse of treated water is only feasible on industries located at Ramos Arizpe.

A representative result of the survey to industries is presented in Table 4. The water consumption column corresponds to the whole volume received for each enterprise. The industrial use column contains the water percentage which is used in manufacturing processes; the zero entries imply all the received water is for human use inside the enterprise (cleaning, cooking, drinking, toilet, etc.). The last column indicates the volume of treated wastewater that each company would be willing to buy for industrial use. 
Table 4. Information about water consumption by industries.

\begin{tabular}{cccc}
\hline Enterprise & Water Consumption L/s & Industrial Use $\%$ & Potential Use of Treated Water L/s \\
\hline E1 & 49.15 & 98 & 44.39 \\
E2 & 47.56 & 100 & 47.56 \\
E3 & 14.27 & 76 & 1.52 \\
E4 & 4.44 & 80 & 0 \\
E5 & 2.53 & 80 & 2.06 \\
E6 & 1.24 & 5 & 0 \\
E7 & 0.63 & 0 & 0 \\
E8 & 0.38 & 95 & 0.38 \\
E9 & 0.28 & 2 & 0.28 \\
E10 & 0.05 & 0 & 0 \\
E11 & 0.05 & 0 & 0.00 \\
E12 & 0.03 & 0 & 0 \\
E13 & 0.01 & 95 & 0 \\
TOTAL & 120.60 & & 96.19 \\
\hline
\end{tabular}

The required water for industrial use (processes operation) for enterprises E1-E3 is more than $90 \%$ of the total water consumption. This corresponds to a potential use of $\sim 95 \mathrm{~L} / \mathrm{s}$ of treated water. The other enterprises should use no more than $2 \mathrm{~L} / \mathrm{s}$ of treated water. These numbers could be attributed to the fact that most of the installed industries operate "dry processes". However, the acceptance of treated wastewater as source of water by industrialists was identified from the surveys and the workshop. Currently, the steel mill DeAcero Ramos Arizpe, which is located close to the SPP, uses $20 \mathrm{~L} / \mathrm{s}$ of treated water. It is expected that new installations in this industry will use $40 \mathrm{~L} / \mathrm{s}$ of treated water from the RAMP, which is $\sim 2 \mathrm{~km}$ away. Another potential user of treated water is Kimberly Clark, which could demand $45 \mathrm{~L} / \mathrm{s}$. Moreover, considering a mean consumption of $0.5 \mathrm{~L} / \mathrm{s}$ by the other enterprises, the total requirement of treated wastewater for industrial applications is not greater than $150 \mathrm{~L} / \mathrm{s}$. This represents $17 \%$ of the current production of treated water by the SPP and RAMP.

\subsubsection{Urban Greening}

The World Health Organization recommends at least $10 \mathrm{~m}^{2}$ of green area per urban inhabitant [56]. Therefore, the water required for this application increases as a direct function of population increase. Moreover, in regions with low precipitation (as is this case for this study) the water assigned for green area management could be as high as that for human consumption. Before 2008, the water used in green areas was extracted from water wells and was of high quality since it fulfilled the standard for human consumption. In addition, drinking water from the municipal distribution network was used for watering some recreational parks. This practice is now being discouraged but remains active despite the disadvantages related to price and drinking water availability. Since 2008, when the municipal WWTPs started operations, the treated water from the BUFP has been used to water the green areas located northeast of Saltillo. The distribution is performed by gravity through an exclusive pipeline network. Also, some tanker trucks are used to transport treated water to places situated outside the distribution system coverage. Due to its localization, this treatment plant is better situated than the other two for irrigation of green areas in Saltillo.

The results of the virtual analysis (example shown in Figure 6) and in situ inspections indicate that there are 582 ha of green areas in Saltillo and Ramos Arizpe (deficit of $\sim 270$ ha in accordance with the $\mathrm{WHO}$ ); it was observed that most of the green areas do not receive enough water. 


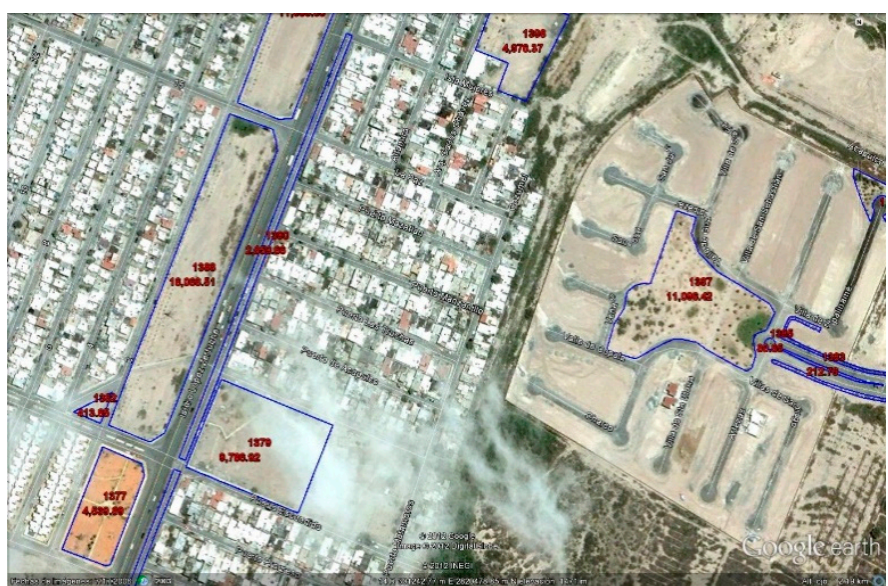

(a)

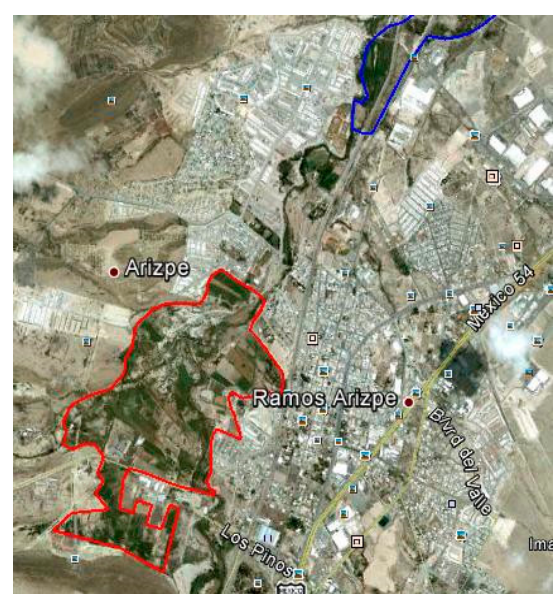

(b)

Figure 6. Virtual analysis of green areas in Saltillo (a) and Ramos Arizpe (b).

According to information provided by municipal authorities in the urban workshop, the volume required to manage the green areas is estimated at $0.9 \mathrm{~L} / \mathrm{s} \cdot \mathrm{ha}$; this is due to the weather in the region and the existing vegetation. A resume of this situation is included in Table 5.

Table 5. Highlights of the urban greening in the study region.

\begin{tabular}{ccc}
\hline Description & Amount & Observations \\
\hline Current volume for green areas & $20 \mathrm{~L} / \mathrm{s}$ & From the BUFP, being 28\% of its capacity \\
Green areas & $582 \mathrm{ha}$ & In both Saltillo and Ramos Arizpe \\
Volume required for current situation & $524 \mathrm{~L} / \mathrm{s}$ & Considering 0.9 L/s.ha \\
Recommended green areas & $7776.22 \mathrm{ha}$ & At least $10 \mathrm{~m}^{2}$ of green area per urban inhabitant \\
Volume for recommended situation & $765 \mathrm{~L} / \mathrm{s}$ & Considering 0.9 L/s.ha and 850 ha \\
Acceptance of treated wastewater & Moderate & Acceptance for indirect contact and non-drinking uses \\
\hline
\end{tabular}

From in situ inspections, it was noted that the vegetation in green areas is not suitable for the region since it requires a considerable amount of water; also, green areas are underwatered. Local adapted or endemic vegetation should be used since they are resistant to large weather variations and able to rise with little water. In order to fulfill the WHO recommendations, the authorities expressed in the workshop the need to increase the surface for green areas and the intention to reach 850 ha. The water required for irrigation of this surface is $765 \mathrm{~L} / \mathrm{s}$; this represents $56 \%$ of the produced wastewater and $88 \%$ of the treated volume.

\subsection{Assessment of Scenarios}

Based on the identified demand and current use of treated wastewater, three distribution scenarios were considered. The scenarios ponder one application as priority and allow meeting the current use of treated water on the other two applications. For the assessment of scenarios, an estimation of the investment to implement them is included. This estimation was done considering the information provided by municipal authorities (responsible for water management in the region); this includes the current prices for the corresponding services in the region. Detailed costs of equipment and operation under the requirements are not presented here in order to simplify the analysis and interpretation. To do a qualitative comparison, some reported works from other places focusing on the priority application are considered.

\subsubsection{Scenario 1: Maximal Application to Agriculture}

In this scenario, the use of treated water in industry remains equal as currently: $20 \mathrm{~L} / \mathrm{s}$; then, additional actions or investments are not required for this application since the distribution system 
is installed and operating. It is worthwhile to mention that the treated water is sold and generates revenues of $\sim 170,000$ USD. On the other hand, since the BUFP is far away from the agriculture zone, this scenario considers the whole effluent from BUFP $(70 \mathrm{~L} / \mathrm{s})$ to be applied for the watering of green urban areas. Presently, only $17 \mathrm{~L} / \mathrm{s}$ is used for this application; the actual distribution system would have to be extended in order to use the whole treated volume. Distribution with tanker trucks is currently done. However, it seems to be expensive, inefficient, and even negative for the environment: the trucks receive little maintenance, large volume of water is lost in the distribution, they use fossil fuels and then usually produce a large amount of $\mathrm{CO}_{2}$ emissions. Finally, the other $1100 \mathrm{~L} / \mathrm{s}$ should be destined to farmers. At present time, there are $35 \mathrm{~km}$ of unlined distribution canals to carry the water to the communal farms.

Thus, Table 6 shows the distribution of wastewater for this scenario and the corresponding estimation of investment that is required to implement it. The first challenge to taking advantage of the treated wastewater for this scenario is the improvement of the distribution system. Sediment must be removed from the existing canals, and in some cases, the canals must be rebuilt. The second challenge concerns the economical aspect. The required investment could be provided by the federal organizations in charge of the agricultural sector in cooperation with local farmers, as well as local authorities. Since the owner of the treated water is the municipal government and because it is used on the watering of public green areas, it is not possible to estimate revenues. These two challenges agree with related studies in other places; the conditions for transport treated water, the kind of crops, the amount of water to be assigned and public policies are important topics. To overcome them, a serious collaboration among the involved sectors is required, which is one of the strategies detected in other studies $[9,10]$.

Table 6. Treated wastewater distribution for scenario 1: maximal reuse for agriculture.

\begin{tabular}{cccccc}
\hline Priority & Secondary & Supply (L/s) & Demand (L/s) & Investment (USD) & Some Related Studies \\
\hline Agriculture & & 1100 & 1100 & 670,000 & \\
& Urban & 70 & 765 & $1,000,000$ & Middle Eastern, North [10], \\
& Industry & 20 & 150 & - & and South Africa [9] \\
Total & & 1200 & 2015 & $1,670,000$ & \\
\hline
\end{tabular}

The third challenge is related to the irrigation and culture techniques. The farmers are used to the current irrigation practices, and it is difficult to persuade them to change their work habits. To overcome this situation, it is advisable to implement some techniques such as drip irrigation and improved aspersion. Then it would be feasible to raise crops with higher value, such as vegetables and fruits. Based on related studies $[1,2,4,7,16,57,58]$ and on the characteristics of the study region (distance between treatment plants and agriculture zone, quality of water, deficit of green areas and scarcity of water), several benefits are expected from this scenario:

- Since more and better-quality water is sent to the Arroyo La Encantada, the ecosystems near this natural stream to could be recovered, such as has been done in other regions.

- The farmers could raise more valuable products and then they could improve their life quality.

- The use of treated water for irrigation of green areas allows decreasing the extraction of drinking water from water wells.

\subsubsection{Scenario 2: Maximal Application for the Industrial Sector}

The priority application in this scenario is the industrial sector; after achieving the requirements from enterprises $(150 \mathrm{~L} / \mathrm{s})$, the other two applications could be attended according to treated water availability and distribution feasibility.

As for the previous scenario, the BUFP is not suitable for distribution to industries; for this reason, the total effluent from this plant $(70 \mathrm{~L} / \mathrm{s})$ is considered for urban greening. It implies the investment also remains similar. Then, the volume of treated water destined for agriculture could be $980 \mathrm{~L} / \mathrm{s}$, 
which represents almost $90 \%$ of the volume considered in scenario 1 for this application; however, the corresponding investment remains similar since the maintenance of canals is required. Table 7 illustrates the respective distribution of treated wastewater.

Table 7. Treated wastewater distribution in scenario 2: maximal reuse in industries.

\begin{tabular}{cccccc}
\hline Priority & Secondary & Supply (L/s) & Demand (L/s) & Investment (USD) & Related Studies \\
\hline Industry & & 150 & 150 & $9,500,000$ & \\
& Agriculture & 980 & 1100 & 670,000 & Iran [13] Spain [8], \\
& Urban & 70 & 765 & $1,000,000$ & Jordan [14], Qatar [17] \\
Total & & 2015 & $11,170,000$ & \\
\hline
\end{tabular}

Kimberly Clark is the main potential customer of treated water, since they expressed the intention to use $45 \mathrm{~L} / \mathrm{s}$. There are two options to providing this volume: (i) from the SPP, and (ii) from the RAMP. The first alternative produces water with high quality but requires the construction of a pipeline system $14 \mathrm{~km}$ long. An advantage of this choice is that some other users could be supplied from the same pipeline. The second option requires a $5 \mathrm{~km}$ pipeline; however, the treated water has a high concentration of solids and could require a tertiary treatment, thus influencing the final price. The second big customer is the new building of the DeAcero steel mill which is $1.6 \mathrm{~km}$ from the RAMP. This enterprise and the local authorities have signed an agreement to provide $40 \mathrm{~L} / \mathrm{s}$ of treated water to the steel mill. The enterprise is responsible for the construction of the distribution lines; the signed agreement stipulates that after some years the infrastructure will be given to the municipality.

It is important to remark that the quality of treated wastewater for industries depends on the kind of processes where the water is applied; in some cases, high quality is required and then, tertiary treatments should be implemented $[8,13,20]$. The big industries operating in the study region requires tertiary treatment due to conductivity and even fecal coliforms content. However, most of industries use dry processes; then, the treated water could be used for other applications. Then, it is important to investigate particular specifications and tropicalize either methods or technology. Besides, even if the main industrial application of treated water in Mexico City is cooling, this is a good example for the study region; in addition, the sold of treated water represent good revenues in Monterrey, therefore, it is advisable to adapt its methodology which includes low price and fiscal benefits.

A challenge identified for this scenario is to persuade enterprises to use treated water and to consolidate the ones which expressed their interest in the industry workshop. This could be done if the government states directives for the industrial sector related to the need to reuse the treated water. Besides, scenario 2 includes the environmental and social benefits identified for the first scenario; besides, economic advantages are forecasted: the treated water can be sold to enterprises, which implies revenues for the municipalities. It is worth mentioning that the price of the treated water should be comparable to the current cost of the water used by the enterprise, which is estimated as $\sim 0.50 \mathrm{USD} / \mathrm{m}^{3}$. Furthermore, an additional environmental benefit is identified: the wastewater used by industries could be interchanged by groundwater. Then it is possible to stop the extraction of more than $3 \mathrm{Mm}^{3} /$ year from the aquifers. This would be an interesting contribution to mitigating the overexploitation of the aquifers of the region, specifically for the Saltillo-Ramos Arizpe aquifer.

\subsubsection{Scenario 3: Maximal Application for Urban Greening}

Green area watering is the priority in this scenario and the other two applications are considered secondary. On the other hand, the current volume $(20 \mathrm{~L} / \mathrm{s})$ destined for industry remains similar in this scenario; then, additional actions or investments are not required. Therefore, the amount of treated water available for agriculture is $415 \mathrm{~L} / \mathrm{s}$, which corresponds to $38 \%$ of the demand in this application. This volume is very low and could cause negative effects to the lifestyle of farmers. Besides, the corresponding investment remains similar as for the previous scenarios since the improvement of 
the distribution systems is strictly necessary for an efficient transportation even of this volume. The distribution of treated water and the estimated investment for this scenario is presented in Table 8.

Table 8. Treated wastewater distribution for scenario 3: maximal reuse in green areas.

\begin{tabular}{cccccc}
\hline Priority & Secondary & Supply (L/s) & Demand (L/s) & Investment (USD) & Some Related Studies \\
\hline Urban & & 765 & 765 & $11,000,000$ & \\
& Agriculture & 415 & 1100 & 670,000 & Turkey [18], Israel [19], \\
\multirow{2}{*}{ Total } & Industry & 20 & 150 & - & China [7] \\
\hline
\end{tabular}

This scenario presents more relevant challenges: (a) the geographic position of the three WWTP is not well situated for an efficient distribution of treated water to urban areas; then, it is necessary to implement a distribution strategy including pipelines and even tanker trucks, (b) the treated water quality of the RAMP is not suitable for this application, advanced treatment should be implemented to reach a good water quality, (c) the implementation of new distribution pipelines could require long time and cause lot of disturbances on the cities circulation, and (d) maybe the most limiting challenge is the required investment, which is very high. These challenges agree the reported in related studies $[7,15,18,19]$. Besides, if all the produced wastewater was collected, the WWTP would be close to its maximal operation condition. Also, the population is expected to increase by 250,000 people over the next 10 years; this implies a wastewater increase of $400 \mathrm{~L} / \mathrm{s}$, which exceeds the current treatment capacity. In addition, the enlargement of green areas should be a direct consequence of the increase of population, according to WHO recommendations [30]. With this perspective, the construction of new treatment plants would be required to fulfill the official standards to watering green areas. The total capacity of those WWTP should be at least $300 \mathrm{~L} / \mathrm{s}$ and should be distributed to reach all the urban green areas. On the other hand, the main benefits of this scenario are social and environmental. The life quality could be improved since green areas are recreational areas and help to regulate temperature on the cities. Moreover, the use of treated water for watering green areas allows decreasing the extraction of water from wells.

\subsubsection{Comparison of Scenarios}

Based on the previous analysis, a comparison of the three considered scenarios is included in this section (Table 9). From this comparison, it is concluded that the second scenario is the most adequate. The demand from the three applications is quite satisfactory: even if the watering of green areas is limited, it is possible to increase the current volume for this application. On the other side, considering the distribution for the other two applications, it is possible to re-activate agricultural activities, increasing the farmer revenues, recover the ecosystem near the Arroyo La Encantada, and to provide wastewater for the potential demand of the industrial sector.

\subsection{Environmental Assessment of the Maximal Application on Industrial Sector}

The environmental performance of the second scenario is assessed by using the Battelle-Columbus method [59-61]. This technique was developed to evaluate water resource planning projects; it is based on a hierarchical arrangement of environmental quality indicators. The major level is composed of four categories: ecology, environmental pollution, esthetics and human interest. Each category considers different environmental components and each component includes several environmental parameters. These parameters are associated to specific characteristics of the studied project, such as land use, water quality, diversity of vegetation types, employment opportunities, etc.; then, they are expressed in different measurement units. In addition, they have a specific level of importance which is determined by a parameter importance unit (PIU). It is worthwhile to mention that the optimal quality of a studied environment counts 1000 units. The environmental quality index (EQI) is introduced as a transformation system in order to obtain homogeneous units for all parameters. These new units 
are called environmental impact units (EIU) and allow global evaluation to be possible. The EIUs are computed for the situation with and without the project implementation; the difference between the two scores represents the environmental change produced by the project, and the amplitude of this change allows generating a flag which indicate how fragile or strong the respective parameter is [60]. Next is a description of the methodology: (i) to obtain the EQI with and without the project implementation by using a transformation function, (ii) to compute the EIU with and without the project implementation as follows: $\mathrm{EIU}=\mathrm{EQI} \times \mathrm{PIU}$; after that, the net change is obtained as: change $=$ $\left(\mathrm{EIU}_{\text {with }}-\mathrm{EIU}_{\text {without }}\right) /\left(\mathrm{EIU}_{\text {without }}\right)$, (iii) to assign a flag for each parameter. Concerning the Ecology category, a major flag is assigned if $0<\mid$ change| and a minor flag is assigned if $5 \mid$ change $\mid<10$. For the other categories, a major flag is assigned if $30<\mid$ change|, and a minor flag is assigned if $30>\mid$ change $\mid$.

Table 9. Scenarios comparison.

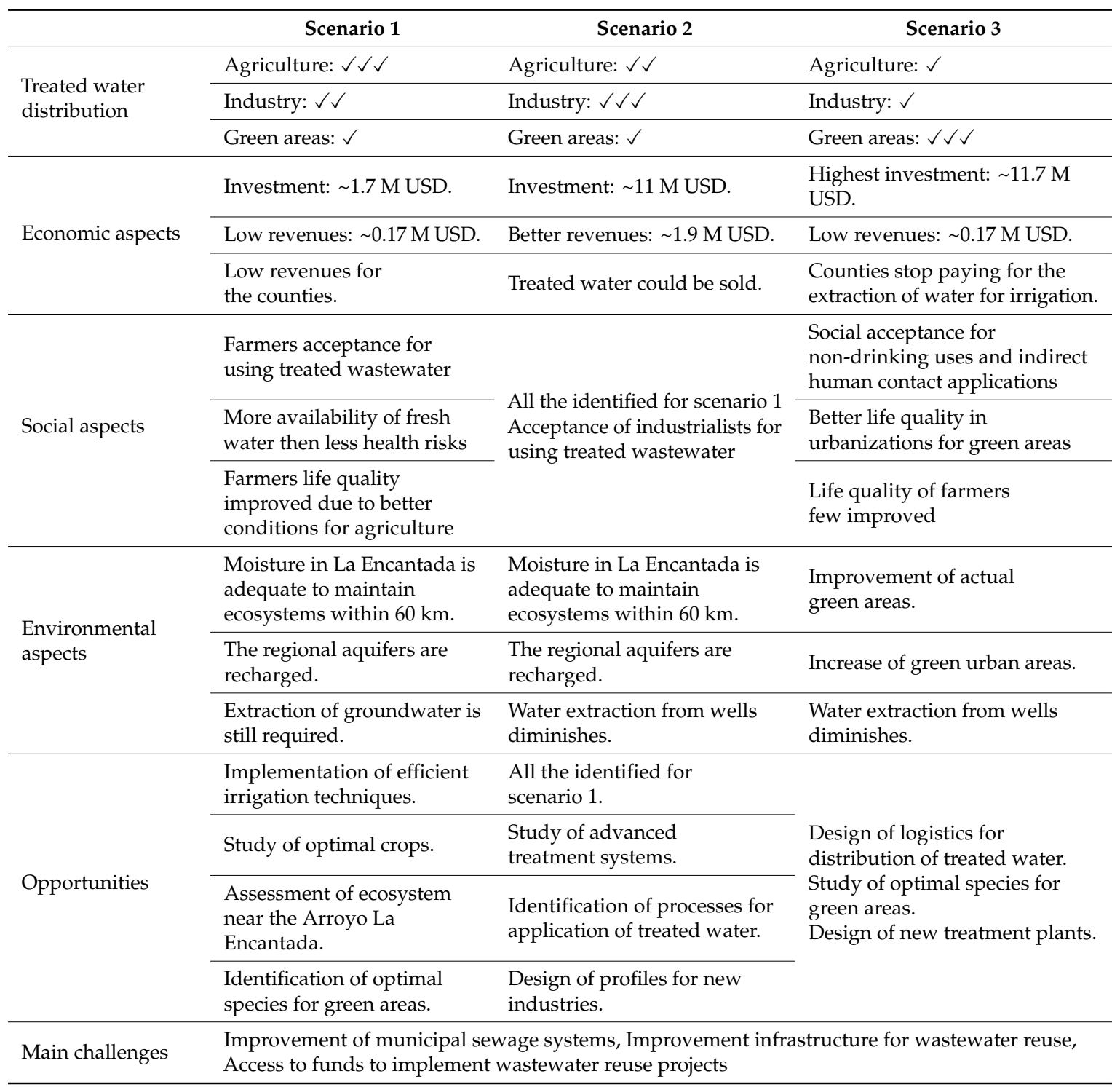

The environmental evaluation of the maximal application of wastewater on the industrial sector is presented on Table 10. To ease the assessment, nine environmental parameters were selected from the four categories as follows. Ecology: crops; environmental pollution: basins hydrologic loss and land use; aesthetics: water appearance, wild animals and variety within vegetation types; human interest: recreation spaces, landscape. It is considered that these parameters are representative of the studied environment. The transformation functions used to obtain the EQIs were taken from reference [60]. The 
PIUs where determined based on the ones used by the Battelle Columbus method [59]; proportional coefficients where used according to the number of parameters on each category.

Table 10. Environmental assessment.

\begin{tabular}{cccccccc}
\hline & \multicolumn{2}{c}{ EQI } & \multicolumn{5}{c}{ EIU Evaluation } \\
\hline Parameters & Without & With & PIU & Without & With & Change & Flag \\
\hline Crops & 0.8 & 0.9 & 240 & 192 & 216 & 12.5 & Major \\
Basins hydrologic loss & 0.9 & 0.95 & 370 & 333 & 351.5 & 6 & Minor \\
Land use & 1 & 0.8 & 32 & 32 & 25.6 & -20 & Minor \\
Water appearance & 0.6 & 0.9 & 105 & 63 & 94.5 & 50 & Major \\
Wild animals & 0.5 & 0.8 & 24 & 12 & 19.2 & 60 & Major \\
Variety within vegetation types & 0.6 & 0.7 & 24 & 14.4 & 16.8 & 17 & Minor \\
Recreation spaces & 0.2 & 0.6 & 51 & 10.2 & 30.6 & 200 & Major \\
Landscape & 0.2 & 0.6 & 51 & 10.2 & 30.6 & 200 & Major \\
Employment opportunities & 0.7 & 0.8 & 103 & 72.1 & 82.4 & 14 & Minor \\
Total & & & 1000 & 738.9 & 867.2 & & \\
\hline
\end{tabular}

Only the land use presents a negative impact, this is mainly due to the enhancing of the current distribution system and the construction of new ones. The other parameters receive positive impacts. Major impact is observed on water appearance, wild animals, recreation spaces and landscape; this is a direct effect of the recovering of the ecosystem on the shore of the Arroyo La Encantada. Related to crops, even if the environmental quality is improved only in $0.1 \mathrm{EQI}$, the global impact is major since this parameter corresponds to the ecology category; in addition, this impact is related to the improvement of the watering and the kind of crops which should be used. The minor impacts are related to basins hydrologic loss, variety within vegetation types and employment opportunities. The first one is the effect of stopping the extraction of water from aquifers as a consequence of the reutilization of treated wastewater. The second one is related to the recovery of ecosystem on the shore of the Arroyo La Encantada. The third one corresponds to the employment of people on the agriculture activities. On the other side, the environmental quality without the project (the current situation) is 738.9 EIU, meanwhile the maximal application of wastewater on industrial activities allows the environmental quality to be improved in $128.3 \mathrm{EUI}$, around $13 \%$.

\subsection{Recommendations for the Future Use of Wastewater}

From the previous analysis, some recommendations related to the main challenges to implement a complete strategy for the systematic use of wastewater in the study region considering the distribution proposed in scenario 2 are proposed:

(a) Improvement and supervision of municipal sewage systems:

Since the main reasons of the water lost are identified (pipeline leakages, incomplete sewage net and irregular practices), the water return could be increased by implementing the next strategies:

- The municipal sewage systems must be updated to enlarge the coverage of wastewater gathering. In addition, discharge of wastewater to the Arroyo La Encantada and irregular practices must be avoided.

- Stricter supervision of the sewage system is required; an alternative is to develop a system based on telemetry including the logistic of supervision and the data acquisition as done for other applications [62-64].

- With these actions, the SPP and BUFP should reach 100\% of their capacity, and the RAMP 70\%. This allows a higher availability of treated wastewater and then a diversification of applications.

(b) Infrastructure for treated wastewater reuse: 
- Monterrey owns a treated wastewater distribution $210 \mathrm{~km}$ long to carry $360 \mathrm{~L} / \mathrm{s}$ (4\%) and Mexico City distributes more than $3700 \mathrm{~L} / \mathrm{s}(\sim 10 \%)$ for reuse. Meanwhile, Saltillo and Ramos Arizpe reuse $40 \mathrm{~L} / \mathrm{s}$; even if the proportion $(4.5 \%)$ is like the one in Monterrey and not too far from the corresponding to Mexico City, the volume is low since the region has water scarcity: wastewater should be better used.

- An important issue is the lack of infrastructure. Currently, the BUFP has a distribution system for treated water $\sim 15 \mathrm{~km}$ long and the SPP a system $1 \mathrm{~km}$ long which is especially used for a steel mill. Even if tanker trucks are also employed, the distributed volume by this way is low and inefficient. Thus, extension of the distribution systems requires to be done.

- The authorities should take advantage of the interest of Kimberly Clark to reuse treated water; this enterprise is the furthest from the SPP in Monterrey direction. Therefore, a pipeline from the SPP could distribute enough treated water to supply the industrial demand in north of Saltillo and Ramos Arizpe. On the other hand, infrastructure for the distribution of wastewater to the agricultural region must be also updated. As aforementioned, several unlined canals require maintenance and even re-construction. Since this kind of distribution is inefficient, better canals should be implemented.

- The BUFP is better situated for reusing on municipal green areas; therefore, the distribution pipeline should be extended. Also, future treatment plants should be implemented based on reuse of treated wastewater.

(c) Sector collaboration and social involvement:

- Regional collaborations are recommended in other places around the world. The involved parties (municipal authorities, federal organisms, nongovernmental organizations, users) should be well coordinated to solve issues in the different stages of the implementation of strategies for the use of treated wastewater.

- The distribution system for industrial use could be developed in collaboration between the municipalities and the interested enterprises. In fact, there is already an accord to build a pipeline from the RAMP to a steel mill; this could be used as a basis to develop additional projects. The enterprises in the Ramos Arizpe industrial parks could provide most of the funds; consequently, they should receive water at low price and fiscal benefits.

- The required investment to carry treated water to agricultural lands could be provided by federal organizations. According to the Mexican compromises regarding the 2030 Agenda for Sustainable Development, federal programs are being developed in order to promote cleaner production, including agriculture and ecosystems conservation. Besides, the current development program of Coahuila state includes the ecosystem conservation and the water conservation. Therefore, projects to reuse treated water on agriculture are susceptible to receive funds and even technical support. In addition, local farmers have expressed willingness to cooperate at least with workforce.

- The funds to complement the distribution of wastewater from the BUFP could be provided by federal organizations or private entrepreneurs; the amortization could be charged to municipal authorities and the final users (people and property developers). In addition, CONAGUA offers funds for projects related to implementation of wastewater treatment plants and reuse of water. The study region could apply for this kind of program.

- Following the directives of the 2030 Agenda and the Development Program, it is advisable to create new laws to promote the integration of wastewater treatment process in the new buildings; the treated water could be employed to water green areas and even used in other applications in the same building or in other close areas. Also, regulations to allow farmers to raise more valuable crops are required.

- On the other hand, the region is home of universities and research centers with experience in the management of natural resources. These institutions could provide their expertise to several activities such as evaluation of crops, irrigation techniques, study of species for green areas, 
evaluation of tertiary systems for wastewater treatment, identification of industrial applications of treated water, sustainability assessment and some others.

- Finally, social involvement is also required. People could be involved in supervision of sewage systems, distribution of wastewater and green areas. In this sense, communication programs to raise awareness on people concerning water relevance in the region are also an important aspect.

\section{Conclusions}

From the integration of information, it was determined that the study region municipal WWTP treats $872 \mathrm{~L} / \mathrm{s}$ of waste water which corresponds to $66 \%$ of the identified wastewater. By improving the wastewater gathering, it is possible to offer $1100 \mathrm{~L} / \mathrm{s}$ for different applications. The quality of the treated wastewater is suitable for different applications, which could be an alternative to the scarcity of water in the region. From the assessment of scenarios, it was found that the best distribution of treated water is: $150 \mathrm{~L} / \mathrm{s}$ for industries, $980 \mathrm{~L} / \mathrm{s}$ for agricultural activities and $70 \mathrm{~L} / \mathrm{s}$ for watering green areas.

The main benefits associated to this distribution are: (a) $120 \mathrm{~L} / \mathrm{s}$ of fresh water could be replaced by treated water, reducing aquifer exploitation, (b) it promotes the re-activation of agriculture and the ecosystems near the Arroyo La Encantada may be preserved, (c) it promotes the application of larger volumes of treated water to green areas. On the other hand, the more relevant issues to be overcome are: (a) improvement of municipal sewage systems and of the infrastructure for reusing wastewater, (b) implementing a strategy to get investment from national organisms, (c) ensuring regional collaboration including municipal and federal governments, industrialists, academic and social sectors. Even if the surveys and workshops allowed us to partially identify the social acceptance of reuse of treated water in the region, an assessment specially focused on social acceptability is required. Also, among the future research on this field should be oriented to: (i) identify emergent pollutants in wastewater, (ii) determine specific industrial applications to develop methods to reach the required quality of treated wastewater, (iii) evaluate the resistance of local species as elements on green urban areas, (iv) determine the best crops for the new conditions of agriculture sector.

Author Contributions: A.V.R. and E.N.A.G. developed the technical and economic analysis as well as the integration of information. G.T.E. and L.S.M. conceived and applied the survey to farmers in order to obtain and analyze the information concerning the agriculture sector; in collaboration with A.V.R. they performed the generation of the information concerning urban greening. L.D.J. and S.C.H. conceived and applied the survey to industries and analyzed the obtained information; also, they wrote the paper.

Funding: This research was funded by Coahuila State Council for Science and Technology (COECYT Coahuila) through project 149646.

Conflicts of Interest: The authors declare no conflict of interest.

\section{References}

1. Vergine, P.; Salerno, C.; Libutti, A.; Beneduce, L.; Gatta, G.; Berardi, G.; Pollice, A. Closing the water cycle in the agro-industrial sector by reusing treated wastewater for irrigation. J. Clean. Prod. 2017, 164, 587-596. [CrossRef]

2. Trat, A.K.; Schwabe, K.A.; Jassby, D. Wastewater reuse for agriculture: Development of a Regional Water Reuse decision-support Model (RWRM) for cost-effective irrigation sources. Environ. Sci. Technol. 2016, 50, 9390-9399. [CrossRef]

3. De Gisi, S.; Casella, P.; Cellamare, C.M.; Ferraris, M.; Petta, L.; Notarnicola, M. Wastewater reuse. Encycl. Sustain. Technol. 2017, 53-68. [CrossRef]

4. Reznik, A.; Feinerman, E.; Finkelshtain, I.; Fisher, F.; Huber-Lee, A.; Joyce, B.; Kan, I. Economic implications of agricultural reuse of treated wastewater in Israel: A statewide long-term perspective. Ecol. Econ. 2017, 222-233. [CrossRef]

5. Becerra-Castro, C.; Lopes, A.R.; Vaz-Moreira, I.; Silva, E.F.; Manaia, C.M.; Nunes, O.C. Wastewater reuse in irrigation: A microbiological perspective on implications in soil fertility and human and environmental health. Environ. Int. 2015, 75, 117-135. [CrossRef] [PubMed] 
6. Elgallal, M.; Fletcher, 1.; Evans, B. Assessment of potential risks associated with chemicals in wastewater used for irrigation in arid and semiarid zones: A review. Agric. Water Manag. 2016, 177, 419-431. [CrossRef]

7. Lyu, S.; Chen, W.; Zhang, W.; Fan, Y.; Jiao, W. Wastewater reclamation and reuse in China: Opportunities and challenges. J. Environ. Sci. 2016, 39, 86-96. [CrossRef] [PubMed]

8. Pintilie, P.; Torres, C.M.; Teodosiu, C.; Castells, F. Urban wastewater reclamation for industrial reuse: An LCA case study. J. Clean. Prod. 2016, 139, 1-14. [CrossRef]

9. Adewumi, J.R.; Ilemobade, A.A.; Van Zyl, J.E. Treated wastewater reuse in South Africa: Overview, potential and challenges. Resour. Conserv. Recycl. 2010, 55, 221-231. [CrossRef]

10. Mizyed, N.R. Challenges to treated wastewater reuse in arid and semi-arid areas. Environ. Sci. Policy 2013, 25, 186-195. [CrossRef]

11. Kalavrouziotis, I.K.; Apostolopoulos, C.A. An integrated environmental plan for the reuse of treated wastewater effluents from WWTP in urban areas. Build. Environ. 2007, 42, 1862-1868. [CrossRef]

12. Hophmayer-Tokich, S.; Kliot, N. Inter-municipal cooperation for wastewater treatment: Case studies from Israel. J. Environ. Manag. 2008, 86, 554-565. [CrossRef] [PubMed]

13. Piadeh, F.; Moghaddam, M.R.A.; Mardan, S. Present situation of wastewater treatment in the Iranian industrial states: Recycle and reuse as a solution for achieving goals of eco-industrial parks. Resour. Conserv. Recycl. 2014, 92, 172-178. [CrossRef]

14. Ammary, B.Y. Wastewater reuse in Jordan: Present status and future plans. Desalination 2007, 211, $164-176$. [CrossRef]

15. Chu, J.; Chen, J.; Wang, C.; Fu, P. Wastewater reuse potential analysis: Implications for China's water resources management. Water Res. 2004, 38, 2746-2756. [CrossRef] [PubMed]

16. Moreti, M.; Van Passel, S.; Camposoe, S.; Pedrero, F.; Dogot, T.; Lebailly, P.; Vivaldi, G.A. Modelling environmental impacts of treated municipal wastewater reuse for tree crops irrigation in the Mediterranean coastal region. Sci. Total Environ. 2019, 660, 1513-1521. [CrossRef] [PubMed]

17. Jasim, S.Y.; Saththasivam, J.; Loganathan, K.; Ogunbiyi, O.O.; Sarp, S. Reuse of Treated Sewage Effluent (TSE) in Qatar. J. Water Process Eng. 2016, 11, 174-182. [CrossRef]

18. Maryam, B.; Büyükgüngör, H. Wastewater reclamation and reuse trends in Turkey: Opportunities and challenges. J. Water Process Eng. 2017. [CrossRef]

19. Garcia, X.; Pargament, D. Reusing wastewater to cope with water scarcity: Economic, social and environmental considerations for decision-making. Resour. Conserv. Recycl. 2015, 101, 154-166. [CrossRef]

20. Šrámková, M.V.; Diaz-Sosa, V.; Wanner, J. Experimental verification of tertiary treatment process in achieving effluent quality required by wastewater reuse standards. J. Water Process Eng. 2018, 22, 41-45. [CrossRef]

21. Norma Oficial Mexicana. NOM-001-ECOL-1996 Limites Máximos Permisibles de Contaminantes en las Descargas de Aguas Residuales en y Bienes Nacionales; Diario Oficial de la Federación: Mexico City, Mexico, 1996.

22. Norma Oficial Mexicana. NOM-003-ECOL-1997 Límites Máximos Permisibles de Contaminantes para las Aguas Residuales Tratadas que se Reúsen en Servicios al Público; Diario Oficial de la Federación: Mexico City, Mexico, 1997.

23. CONAGUA. Statistics on Water in Mexico. 2018. Available online: https://www.gob.mx/conagua/acciones-yprogramas/publicaciones-estadisticas-y-geograficas-60692 (accessed on 7 March 2019).

24. Jiménez-Cisneros, B. 2012 Guidelines for the Water Reuse. Available online: https://www3.epa.gov/region1/ npdes/merrimackstation/pdfs/ar/AR-1530.pdf (accessed on 7 March 2019).

25. López-Morales, C.A.; Rodríguez-Tapia, L. On the economic analysis of wastewater treatment and reuse for designing strategies for water sustainability: Lessons from the Mexico Valley Basin. Resour. Conserv. Recycl. 2019, 140, 1-12. [CrossRef]

26. Escalante, V.; Cardoso, L.; Ramírez, E.; Moeller, G.; Mantilla, G.; Montecillos, J.; Servín, C.; Villavicencio, F. El Reuso del Agua Residual Tratada en México. Available online: www.bvsde.paho.org/bvsacd/agua2003/reus. pdf (accessed on 7 March 2019).

27. Romero, M.S.; Salazar, L.E.; Viau, E.; Peccia, J.; Mendoza, L.; Ruvalcaba, G.; Figueroa, M. Contaminación y Medio Ambiente en Baja California. 2006. Available online: https://books.google.com.mx/books?isbn= 9707018593 (accessed on 7 March 2019).

28. Lencioni, V.; Carranza, C.; Vega, A.; Vega, H. Water Reuse in Mexico. Mexico Water Report. 2011. Available online: http://www.lgaconsulting.com/water/IE-MexicoWaterReport-2011Winter-WaterReuseInMexico.html (accessed on 7 March 2019). 
29. Cohen, A.; Mamane, H.; Lester, Y. Reutilizacion de Aguas Residuales en México: Caso Sonora. 2015. Available online: http://www2.congreso.gob.pe/sicr/cendocbib/con5_uibd.nsf/EACED48F3063BA6D05258234005FDCE1/ \$FILE/13.REUTILIZACIÓN-AR-SON.pdf (accessed on 7 March 2019).

30. WHO. Guidelines for the Safe Use of Wastewater, Excreta and Grey Water. 2006. Available online: http://whqlibdoc.who.int/publications/2006/9241546859_eng.pdf?ua=1 (accessed on 7 March 2019).

31. ONU. Transforming Our World: The 2030 Agenda for Sustainable Development. 2015. Available online: sustainabledevelopment.un.org/post2015/transformingourworld (accessed on 11 April 2019).

32. CONAGUA. Programa Contra Contingencias Hidráulicas para la Zona Urbana de Ramos Arizpe, Coahuila. 2016. Available online: https://www.gob.mx/cms/uploads/attachment/file/281365/ZONA_URBANA_ RAMOS_ARIZPE_COAH.pdf (accessed on 7 March 2019).

33. CONAGUA. Consulta a la Base de Datos del REPDA. 2019. Available online: https://app.conagua.gob.mx/ Repda.aspx (accessed on 7 March 2019).

34. INEGI. 2019. Available online: https://www.inegi.org.mx/temas/manufacturasexp/default.html\#Herramientas (accessed on 7 March 2019).

35. SEMARNAT. 2015. Available online: http://www.sema.gob.mx/SRN/SIIAEC/POETE/CUADROS/Cuadro_ 41_Disponibilidad_media_anual.pdf (accessed on 7 March 2019).

36. Akhoundi, A.; Nazif, S. Sustainability assessment of wastewater reuse alternatives using the evidential reasoning approach. J. Clean. Prod. 2018, 195, 1350-1376. [CrossRef]

37. Aguilera-González, E.N.; Valdés-Ramos, A.; Tobón-Echeverri, G.; Carlos-Hernández, S.; Samaniego-Moreno, L.; Alvarez-Garza, M.A.; Díaz-Jiménez, L. Analysis of the Production and Treatment of Wastewater in the Southeast of Coahuila, Mexico. J. Agric. Environ. Sci. 2015, 4, 155-162. [CrossRef]

38. Martines Santos, M.; Lanzén, A.; Unda-Calvo, J.; Martín, I.; Garbisu, C.; Ruiz-Romera, E. Treated and untreated wastewater effluents alter river sediment bacterial communities involved in nitrogen and sulphur cycling. Sci. Total Environ. 2018, 633, 1051-1061. [CrossRef]

39. Contreras, J.D.; Meza, R.; Siebe, C.; Rodríguez-Dozal, S.; López-Vidal, Y.A.; Castillo-Rojas, G.; Amieva, R.I.; Solano-Gálvez, S.G.; Mazari-Hiriart, M.; Silva-Magaña, M.A.; et al. Health risks from exposure to untreated wastewater used for irrigation in the Mezquital Valley, Mexico: A 25-year update. Water Res. 2017, 123, 834-850. [CrossRef]

40. Williams, M.; Kookana, R.S.; Mehta, A.; Yadav, S.K.; Tailor, B.L.; Maheshwari, B. Emerging contaminants in a river receiving untreated wastewater from an Indian urban centre. Sci. Total Environ. 2019, 647, 1256-1265. [CrossRef]

41. Boeriu, L.M.; Cirstolovean, I.L.; Fratu, M.; Nastac, C. The tertiary treatment stage of wastewater. Bull. Transilv. Univ. Braşov. 2013, 6, 207-212. Available online: http://aspeckt.unitbv.ro/jspui/bitstream/123456789/1594/1/ 01\%20boieriu.pdf (accessed on 7 March 2019).

42. Huang, L.Y.; Lee, D.J. Membrane bioreactor: A mini review on recent R\&D works. Biores. Technol. 2015, 194, 383-388. [CrossRef]

43. Kovac Kralj, A. The re-usage of wastewater within industry: The positive impacts of contaminants. J. Clean. Prod. 2015, 95, 124-130. [CrossRef]

44. Cooper, R.C. The hygienic aspects of wastewater reuse. Waste Manag. Res. 1991, 9, 373-377. [CrossRef]

45. Liberti, L.; Notarnicola, M.; Petruzzelli, D. Advance treatment for municipal wastewater reuse in agriculture. UV disinfection: Parasite removal and by-product formation. Desalination 2002, 152, 315-324. [CrossRef]

46. Mutengu, S.; Hoko, Z.; Makoni, F.S. An assessment of the public health hazard potential of wastewater reuse for crop production. A case of Bulawayo city, Zimbabwe. Phys. Chem. Earth 2007, 32, 1195-1203. [CrossRef]

47. Al-Jassim, N.; Ansari, M.I.; Harb, M.; Hong, P.-Y. Removal of bacterial contaminants and antibiotic resistance genes by conventional wastewater treatment processes in Saudi Arabia: Is the treated wastewater safe to reuse for agricultural irrigation? Water Res. 2015, 73, 277-290. [CrossRef]

48. Ruiz Morales, B. Valor de la Producción de las Actividades Agrícola-Ganaderas Realizadas con Aguas Residuales Tratadas en Comunidades Ejidales y Pequeñas Propiedades del Municipio de Ramos Arizpe, Coahuila. Master's Thesis, Universidad Autónoma Antonio Narro, Coah, Mexico, 2013. Available online: http://repositorio.uaaan.mx:8080/handle/123456789/5333 (accessed on 7 March 2019).

49. Sáenz Forero, R. Reuso de Aguas Residuales pre-Tratadas en Agricultura y Piscicultura. 1986. Available online: www.bvsde.paho.org/bvsacd/scan2/017891/017891.pdf (accessed on 7 March 2019). 
50. Moscoso, J. Aspectos Técnicos de la Agricultura con Aguas Residuales. 1995. Available online: www.bvsde. ops-oms.org/bvsair/e/repindex/repi84/vleh/fulltext/acrobat/moscoso.pdf (accessed on 7 March 2019).

51. Zamora Guajardo, R. Utilización de Aguas Negras en el Cultivo de Triticale (X. Triticosecale Wittmack), Variedad AN-57 para la Producción de Forraje, Utilizando como Testigo Agua Normal. Master's Thesis, Universidad Autónoma Antonio Narro, Coah, Mexico, 1998. Available online: http://repositorio.uaaan.mx:8080/xmlui/ handle/123456789/1/browse?value=ZAMORA+GUAJARDO\%2C+RAMON\&type=author (accessed on 7 March 2019).

52. Cisneros Estrada, O.X.; Gonzalez Meraz, J.; Fuentes Ruiz, C. Perspectiva de Aprovechamiento de las Aguas Residuales en la Agricultura. 2001. Available online: http://cenca.imta.mx/pdf/43978Pri.pdf (accessed on 7 March 2019).

53. Murillo Amador, B.; Escobar, A.; Fraga Mancillas, H.; Pargas Lara, R. Rendimiento de grano y forraje de líneas de triticale y centeno en Baja California Sur, México. Rev. Fitotec. Mex. 2001, 24, 145-153. Available online: https://www.revistafitotecniamexicana.org/documentos/24-2/3r.pdf (accessed on 7 March 2019).

54. Plevich, J.O.; Delgado, A.R.S.; Saroff, C.; Tarico, J.C.; Crespi, R.J.; Barotto, O.M. El cultivo de alfalfa utilizando agua de perforación, agua residual urbana y precipitaciones. Rev. Bras. Eng. Agric. Ambient 2012, 16, 1353-1358. [CrossRef]

55. Montemayor Trejo, J.A.; Woo Reza, J.L.; Munguía López, J.; Román López, A.; Segura Castruita, M.A.; Yescas Coronado, P.; Frías Ramírez, E. Producción de alfalfa (Medicago sativa L.) cultivada con riego sub-superficial y diferentes niveles de fósforo. Rev. Mex. Cienc. Agric. 2012, 3, 1321-1332. Available online: http://www. scielo.org.mx/scielo.php?script=sci_arttext\&pid=S2007-09342012000700003\&lng=es\&nrm=iso (accessed on 7 March 2019).

56. Grandjean, A.C. Water Requirements, Impinging Factors, and Recommended Intakes. Available online: www.who.int/water_sanitation_health/dwq/nutrientschap3.pdf (accessed on 7 March 2019).

57. Kumar, D.; Hiremath, A.M.; Asolekar, S.R. Integrated management of wastewater through Sewage Fed Aquaculture for Resource Recovery and Reuse of Treated Effluent: A case study. International Conference on Environmental Science and Development. APCBEE Procedia 2014, 10, 74-78. [CrossRef]

58. Rodenas, M.A.; Albacete, M. The River Segura: Reclaimed water, recovered river. J. Water. Reuse Desal. 2014, 4, 50-57. [CrossRef]

59. Dee, N.; Baker, J.; Drobny, N.; Duke, K.; Whitman, I.; Fahringer, D. An environmental evaluation system for water resource planning. Water Resour. Res. 1973, 9, 523-535. [CrossRef]

60. Conesa Fernández-Vítora, V. Methodological Guide for the Environmental Impact Assessment, 4th ed.; Ediciones Mundi-Prensa: Madrid, Spain, 2003; pp. 253-300. (In Spanish)

61. Wagh, C.H.; Gujar, M.G. The environmental impact assessment by using the Battelle Method. Int. J. Sci. Res. 2014, 3, 82-86.

62. Colomina, I.; Molina, P. Unmanned aerial systems for photogrammetry and remote sensing: A review. ISPRS J. Photogramm. Remote Sens. 2014, 92, 79-97. [CrossRef]

63. Gago, J.; Douthe, C.; Coopman, R.E.; Gallego, P.P.; Ribas-Carbo, M.; Flexas, J.; Escalona, J.; Medrano, H. UAVs challenge to assess water stress for sustainable agriculture. Agric. Water Manag. 2015, 153, 9-19. [CrossRef]

64. Aries Rokhmana, C. The potential of UAV-based remote sensing for supporting precision agriculture in Indonesia. Procedia Environ. Sci. 2015, 24, 245-253. [CrossRef]

(C) 2019 by the authors. Licensee MDPI, Basel, Switzerland. This article is an open access article distributed under the terms and conditions of the Creative Commons Attribution (CC BY) license (http://creativecommons.org/licenses/by/4.0/). 